\title{
Feeding habits of Calanus sinicus (Crustacea: Copepoda) during spring and autumn in the Bohai Sea studied with the herbivore index
}

\author{
GUANG-TAO ZHANG ${ }^{1}$, CHAO-LUN LI ${ }^{1}$, SONG SUN ${ }^{1}$, HONG-YAN ZHANG ${ }^{1}$, \\ JUN SUN ${ }^{1}$ and XIU-REN NING ${ }^{2}$ \\ ${ }^{1}$ Key Laboratory of Marine Ecology and Environmental Sciences, Institute of Oceanology, Chinese Academy of Sciences, \\ 7 Nanhai Road, Qingdao, 266071, China. E-mail: sunsong@ms.qdio.ac.cn \\ ${ }^{2}$ Second Institute of Oceanography, State Oceanic Administration, Hangzhou 310012, China.
}

\begin{abstract}
SUMMARY: Pigment ingestion rate (PIR) and egg production rate (EPR) of the dominant copepod Calanus sinicus, as well as chlorophyll- $a$ concentration and phytoplankton assemblages were measured in the Bohai Sea, North China in June 1997, October 1998 and May 1999. A herbivore index (H) was also calculated as the carbon specific ratio of PIR and EPR, in order to investigate its feeding habits in the spring and autumn phytoplankton bloom respectively. On average, chlorophyll- $a$ concentration was relatively similar $\left(1-1.34 \mathrm{mg} \mathrm{m}^{-3}\right)$ in the three cruises, but PIR was quite different. It was $3.24 \mu \mathrm{g} \mathrm{C}$ female $^{-1}$ $\mathrm{d}^{-1}$ in October, equivalent to one half of the PIR for June and one third of the PIR for May. Average EPR was highest in May, and quite similar during the other two months. According to $\mathrm{H}$ values, herbivorous feeding contributed $100 \%$ of the egg production of $C$. sinicus in June, $82.5 \%$ in May, but only $47.8 \%$ in October. It is possible that omnivorous feeding of $C$. sinicus in October was induced by a prevalence of large-sized diatoms and sufficient non-phytoplankton food resources during the autumn bloom period.
\end{abstract}

Keywords: Calanus sinicus, feeding habits, fecundity, ingestion, herbivore index, Bohai Sea.

RESUMEN: HÁbitos ALIMENTICIOS DE CALANUS SINUCUS (CRustaCEA: COPEPODA) DURANTE PRIMAVERA Y OTOÑo EN EL MAR BOHAI, INVESTIGADOS MEDIANTE UN ÍNDICE DE HERBIVORÍA. - La tasa de ingestión de pigmentos (PIR) y la tasa de producción de huevos (EPR) del copépodo dominante Calanus sinicus ha sido determinada, conjuntamente con la concentración de clorofila- $a$ y la composición del fitoplancton, en el mar de Bohai, norte de China, en junio 1997, octubre 1998 y mayo 1999. Para investigar los hábitos alimenticios durante los blooms de fitoplancton de primavera y otoño se ha determinado un índice de herbivoría $(\mathrm{H})$, calculado como el cociente de las tasas específicas PIR y EPR en carbono. En promedio, la concentración de clorofila-a fue relativamente similar (1-1,34 $\left.\mathrm{mg} \mathrm{m}^{-3}\right)$ en las tres campañas oceanográficas. Pero los valores de PIR difirieron bastante, variando desde $3,24 \mu \mathrm{g} \mathrm{C}_{\text {hembra }}^{-1} \mathrm{~d}^{-1}$ en octubre a valores un medio y un tercio de dicho valor, respectivamente, en junio y mayo. Los valores promedio de EPR fueron máximos en mayo, y bastante similares durante los otros dos meses. Según los valores del índice H obtenidos, la herbivoría contribuyó un $100 \%$ en la producción de huevos de $C$. sinicus en junio y un $82,5 \%$ en mayo, mientras que sólo explicó un $47,8 \%$ de la producción de huevos en octubre. este estudio sugiere que la alimentación omnivora de $C$. sinicus en octubre fue inducida por la prevalencia de diatomeas de gran tamaño y la presencia suficiente de alimento no fitoplanctónico durante el periodo del bloom otoñal.

Palabras clave: Calanus sinicus, hábitos alimenticios, fecundidad, ingestión, índice de herbivoría, mar Bohai.

\section{INTRODUCTION}

In the past 20 years, many "herbivorous" copepods were found exploiting food items other than phytoplankton, such as detritus, bacteria and proto- zoan (Kleppel, 1993; Harris, 1996). Copepod consumption of these non-phytoplankton items probably plays an important role in both the carbon cycling and zooplankton population dynamics. Many forms of primary production, such as dis- 
solved organic matters and tiny cells, are inaccessible to large consumers before being repackaged in the microbial food loop. Copepods are key intermediaries through which this part of primary production re-enters the main food web. In laboratory studies, pure diatom diets can lead to deleterious effects on copepod reproduction and development (Ban et al., 1997; Ianora et al., 2003), but in some other studies these effects can be overcome by omnivorous feeding (Ban et al., 2000; Kang and Poulet, 2000; Lacoste et al., 2001; Turner et al., 2001; Miralto et al., 2003).

However, until now, it has been hard to tell exactly what proportion of the diet of certain copepod species is made up of phytoplankton and non-plant items. The Gut fluorescence method can only quantify plant compositions. Currently, the most reliable method for determining omnivorous feeding is bottle incubation and microscopic counting, which are time-consuming and less precise because of bottle effects and potential problems with food chain effects (Båmstedt et al., 2000). A simple approach was suggested for estimating magnitude of omnivorous feeding from the ratio of egg production rate (EPR) and pigment ingestion rates (PIR), assuming that gross growth efficiency $\left(\mathrm{K}_{1}\right)$ is a known constant and females spend all the assimilated energy on reproduction (Dam et al., 1994; Peterson and Dam, 1996). This method is at least half quantitative. Using this method we can re-analyze PIR and EPR, which are frequently measured in many copepod species, for additional information on feeding habits. ICES recommended this method in its zooplankton manual (Båmstedt et al., 2000), but it is unfortunate that no subsequent research has been conducted following this method.

The Bohai Sea, with an average depth of $18 \mathrm{~m}$, is an inland sea in North China which is heavily influenced by human activities. It has been selected as one of the China-GLOBEC study areas. Primary production in the Bohai Sea, especially in coastal areas, is much higher than in the Yellow and East China Seas (Yu and Li, 1993). Seasonal variation of phytoplankton biomass is usually bimodal, with a major bloom after April and a secondary peak from September to October. Calanus sinicus is a dominant zooplankton species in the Bohai Sea, and traditionally treated as a pure herbivore. Its feeding selectivity is thought to be of great importance to the tropho-dynamics in this ecosystem. During three cruises carried out in this area in June 1997, October 1998, and May 1999, egg production and pigment ingestion rates were measured synchronously. Grazing impact of copepods on phytoplankton during May and October has already been published (Li et al., 2003). In this article, both PIR and EPR of $C$. sinicus were converted into carbon specified values, and a herbivore index was also calculated following the method proposed by Dam et al. (1994). We aimed to investigate the feeding habits of $C$. sinicus, i.e. herbivorous or omnivorous, in spring and autumn respectively, and to explain in more detail its relation with phytoplankton abundance and assemblages.

\section{MATERIALS AND METHODS}

\section{Sampling}

Field investigations were carried out in the Bohai Sea as part of the Chinese GLOBEC projects, from 1 to 6 June 1997, 1 to 7 October 1998 and 1 to 7 May 1999 respectively. During each of these three cruises, five anchor stations were included (Fig. 1) and at each station $24 \mathrm{~h}$ continuous observations was carried out. The same stations were investigated in the last two cruises, except station E1, which was cancelled in October 1998 due to bad weather. At each station, vertical profiles of temperature and salinity were measured with a Sea-Bird (SBE 19) CTD. Seawater was collected using Niskin bottles at different depths $(0,5,10,20,30,40 \mathrm{~m}$ and $2 \mathrm{~m}$ above the sea floor). From each depth, $200 \mathrm{ml}$ of water was filtered onto glassfiber (Whatman GF/F) filters to determine chlorophyll- $a$ concentration using a Turner Designs fluorometer. Chl- $a$ concentration for each station was

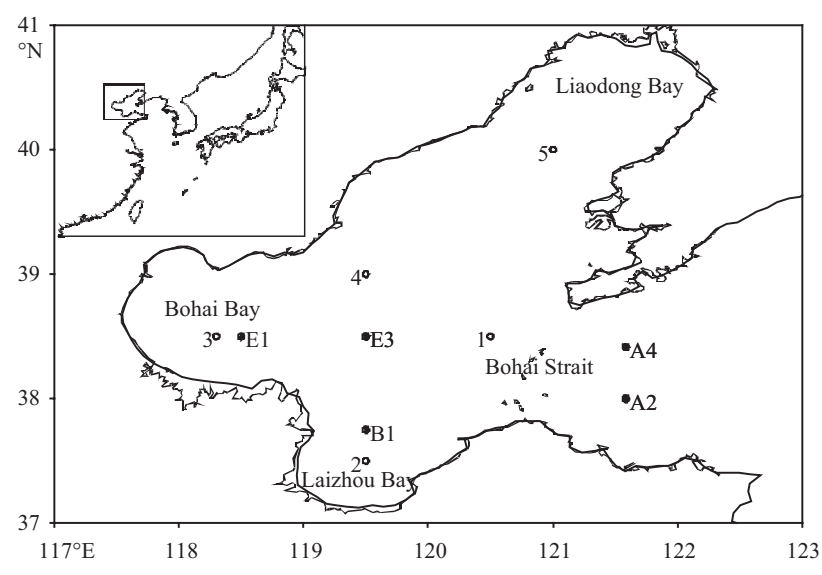

FIG 1. - Study sites (Stations 1 to 5 were studied in June, Station A2, A4, B1, E1, E3 were repeated in the other two cruises. The inlet represents the position of the Bohai Sea). 
measured every 6 hours and the final concentration was calculated as the average over a daily cycle. Phytoplankton assemblages were identified to genus level from water sampled by the Niskin bottle in the June cruise. In May and October samples were collected with nets (mouth opening: $0.1 \mathrm{~m}^{2}$, mesh size: $76 \mu \mathrm{m}$ ) towed vertically from $2 \mathrm{~m}$ above the bottom to the surface. All the samples were fixed with $2 \%$ formalin seawater and enumerated under a microscope in the laboratory. Phytoplankton assemblages were sampled every 6 hours, and the final values in our results were averages over a daily cycle.

\section{Pigment ingestion rate}

Living zooplankton samples from vertical net (mouth opening: $0.5 \mathrm{~m}^{2}$, mesh size: $330 \mu \mathrm{m}$, length: $2 \mathrm{~m}$, sealed cod-end) tows were poured into soda/seawater solutions $(1: 5, \mathrm{v} / \mathrm{v})$. Then sieved through $1000 \mu \mathrm{m}$ meshes and gently rinsed with filtered seawater. For each sample, 20 adult females were sorted under dim light, and put into $10 \mathrm{ml}$ glass centrifuge tubes with $90 \%$ acetone solution. After extraction in the dark at $-30^{\circ} \mathrm{C}$ for $24 \mathrm{~h}$, gut pigment content (GPC) was measured on a Turner Designs fluorometer following the procedure of Mackas and Bohrer (1976) and Wang and Conover (1986). A carbon/chlorophyll ratio (C:Chl $a$ ) of 50 was adopted here to convert chl- $a$ concentration into phytoplankton carbon (Atkinson, 1996). Gut evacuation rate $(k)$ was measured with living samples following the procedure of (Mackas and Bohrer, 1976; Willason and Cox, 1986). Living individuals were incubated in filtered seawater with non-fluorescent charcoal, and gut pigment content was measured initially and after 10, 20, 30, 60, 90, 120 minutes respectively. $k$ was also calculated using a negative exponential equation. PIR was calculated from the expression:

$$
P I R=G P C \times k
$$

where GPC is also the average value over a daily cycle.

\section{Egg production rate}

At each station, net zooplankton samples were diluted into a $20 \mathrm{~L}$ bucket full of surface seawater and immediately delivered to the onboard laboratory, where healthy adult females were sorted out straight away. Plastic bottles $(350 \mathrm{ml})$ partitioned with a 330 $\mu \mathrm{m}$ mesh screen at the bottom were used to avoid cannibalism. Five adult females per bottle were incubated in $70 \mu \mathrm{m}$ filtered seawater in a 12:12 h L:D cycle (Runge, 1985; Plourde and Runge, 1993), and five replicates were set in each experiment. It has been suggested that egg production rate calculated in this way represents natural conditions well (Runge and Roff, 2000). Eggs spawned during the first $24 \mathrm{~h}$ were counted, and then transferred into petri dishes for hatching. Hatching success was calculated when the eggs remaining in the dishes didn't hatch any more. As thermal stratification was not evident during our study, the temperature in the incubator was set to equal the surface temperature at each station. Since bias might arise from diel spawning rhythms, the experiments were repeated 12 hours later and EPR was calculated as the average of the two replicate experiments. Both ingestion and reproduction experiments failed at certain stations because of low female density or bad weather.

\section{Egg production efficiency and herbivore index}

Since gross growth efficiency $\left(\mathrm{K}_{1}\right)$ of $C$. sinicus is unavailable, a constant 0.33 suggested for common copepod species was adopted in this study (Båmstedt et al., 2000). EPR was converted into carbon weight after multiplying egg number by $0.20 \mu \mathrm{g}$ C per egg (Uye, 1988). Gut pigment loss, estimated simultaneously, varied from 0 to $37 \%$ (13\% on average), which was in the same range as previous studies. However, PIR was not rectified with this result due to the large differences in water temperature and chl- $a$ concentration (Li et al., 2003). Subsequently, the egg production efficiency $\left(\mathrm{K}_{1}{ }^{\prime}\right)$ was calculated as EPR/PIR. If the target specie is a pure herbivore, $\mathrm{K}_{1}{ }^{\prime}$ should approach 0.33 , whereas values higher than 0.33 were considered to be induced by omnivorous feeding. Therefore, the fraction of egg production contributed by herbivorous feeding is represented by the herbivore index $(\mathrm{H})$, and was calculated as:

$$
\mathrm{H}=0.33 / \mathrm{K}_{1}{ }^{\prime}
$$

\section{RESULTS}

\section{Environment conditions}

The deepest station (51.4 m) A4 was located at the centre of Bohai Strait, and the shallowest B1 
$384 \cdot$ G.T. ZHANG et al.

TABLE 1.- Pigment ingestion rate, egg production rate, hatching success, egg production efficiency $\left(\mathrm{K}_{1}^{\prime}\right)$ and herbivore index $(\mathrm{H})$ of $C$. sinicus and environmental conditions at each station monitored during the three cruises in the Bohai Sea (Depth, temperature $-\mathrm{T}$, Chlorophyll- $a$ concentration-Chl $a$, total phytoplankton cell concentration-TCC, ratios between dinoflagellates and diatoms-F/D)

\begin{tabular}{|c|c|c|c|c|c|c|c|c|c|c|c|}
\hline Time & Station & $\begin{array}{l}\text { Water Depth } \\
\text { (m) }\end{array}$ & $\begin{array}{c}\mathrm{T} \\
\left({ }^{\circ} \mathrm{C}\right)\end{array}$ & $\begin{array}{c}\mathrm{Chla} \\
\left(\mathrm{mg} \mathrm{m}^{-3}\right)\end{array}$ & $\begin{array}{c}\text { TCC } \\
\text { (cells } \mathrm{m}^{-3} \text { ) }\end{array}$ & $\mathrm{F} / \mathrm{D}$ & $\begin{array}{c}\text { PIR } \\
\left(\mu \mathrm{g} \mathrm{C} \text { female }^{-1} \mathrm{~d}^{-1}\right)\end{array}$ & $\begin{array}{c}\text { EPR } \\
\left(\mu \mathrm{g} \mathrm{C} / \text { eggs female } \mathrm{e}^{-1} \mathrm{~d}^{-1}\right)\end{array}$ & $\begin{array}{l}\text { Haching } \\
{ }^{1)}(\%)\end{array}$ & $\mathrm{K}_{1}^{\prime}$ & $\underset{(\%)}{\mathrm{H}}$ \\
\hline $1-15$ th & 1 & 29.8 & 12.4 & 1.03 & - & 0.06 & 1.57 & $0.82 / 4.1$ & - & 0.52 & 63.5 \\
\hline June & 2 & 18.1 & 17.0 & 1.32 & - & 0.07 & - & $2.28 / 11.4$ & - & & - \\
\hline \multirow{4}{*}{1997} & 3 & 19.3 & 17.5 & 1.13 & - & 0.01 & 7.33 & $2.70 / 13.5$ & - & 0.37 & 89.2 \\
\hline & 4 & 27.2 & 14.8 & 0.6 & - & 0.17 & 5.06 & - & - & & - \\
\hline & 5 & 29.2 & 13.9 & 1.35 & - & 0.03 & 11.86 & $2.62 / 13.1$ & - & 0.22 & 150.0 \\
\hline & $\mathrm{Ave} \pm \mathrm{SD}$ & & & $1.09 \pm 0.30$ & & & $6.46 \pm 4.31$ & $2.11 \pm 0.88$ & & 0.33 & 100.0 \\
\hline $1-7$ th & A2 & 35.9 & 22.3 & 1.48 & 955169 & 0.06 & 4.57 & $2.80 / 14.0$ & 81.0 & 0.61 & 54.1 \\
\hline October & $\begin{array}{r}\mathrm{r} \\
\mathrm{A} 4\end{array}$ & 51.4 & 18.7 & 0.44 & 54120 & 0.07 & 1.18 & $2.32 / 11.6$ & 83.1 & 1.97 & 16.8 \\
\hline \multirow[t]{3}{*}{1998} & B1 & 16.2 & 22.8 & 2.12 & 841173 & 0.02 & 5.69 & - & - & & - \\
\hline & E3 & 27.6 & 23.0 & 1.31 & 415118 & 1.19 & 1.53 & $1.58 / 7.9$ & 86.3 & 1.03 & 32.0 \\
\hline & Ave \pm SD & & & $1.34 \pm 0.69$ & & & $3.24 \pm 2.23$ & $2.23 \pm 0.61$ & $83 \pm 7.3$ & 0.69 & 47.8 \\
\hline $1-7$ th & A2 & 35.4 & 7.7 & 0.22 & 171638 & 0.16 & - & $2.80 / 14.0$ & 97.6 & & - \\
\hline May & A4 & 50.6 & 7.0 & 0.32 & 49424 & 0.17 & - & $3.54 / 17.7$ & 96.5 & & - \\
\hline \multirow[t]{4}{*}{1999} & B1 & 15.7 & 11.8 & 2.90 & 81178 & 6.48 & 3.06 & $2.26 / 11.3$ & 93.4 & 0.74 & 44.6 \\
\hline & E1 & 20.3 & 10.3 & 1.39 & 186942 & 0.00 & 10.38 & $3.34 / 16.7$ & 98.4 & 0.32 & 103.1 \\
\hline & E3 & 25.8 & 8.1 & 1.68 & 154135 & 0.00 & 12.98 & $5.80 / 29.0$ & 99.8 & 0.45 & 73.3 \\
\hline & $\mathrm{Ave} \pm \mathrm{SD}$ & & & $1.30 \pm 1.10$ & & & $8.81 \pm 5.14$ & $3.55 \pm 1.35$ & $97.1 \pm 3.7$ & 0.40 & 82.5 \\
\hline
\end{tabular}

$(15.7 \mathrm{~m})$ was in Laizhou Bay. Average water temperature of each station was lowest in May 1999 $\left(7.0-11.8^{\circ} \mathrm{C}\right)$, then June $1997\left(12.4-17.5^{\circ} \mathrm{C}\right)$, and highest in October $1998\left(18.7-23.0^{\circ} \mathrm{C}\right)($ Table 1). Average chl- $a$ concentration was 1.30 and 1.34 $\mathrm{mg} \mathrm{m}^{-3}$ in May and October, but comparatively low in June at $1.09 \mathrm{mg} \mathrm{m}^{-3}$. Geographical variation of chl- $a$ concentration was evident, especially in May, when it was as high as $2.90 \mathrm{mg} \mathrm{m}^{-3}$ in Laizhou Bay but only $0.22 \mathrm{mg} \mathrm{m}^{-3}$ in Bohai Strait.

Diatoms dominated the phytoplankton from both net and bottle samples except at two stations: Ceratium spp. prevailed at E3 in October and Noctiluca spp. at B1 in May (Fig. 2). The most abundant diatom genera in June were Rhizosolenia spp., Melosira spp. and Cyclotella spp., and in October they were Coscinodiscus spp. and Cheatoceros spp., while in May they were these two combined with Rhizosolenia spp. However, in many cases the highest percentage was represented by some of the other less abundant diatoms. Since phytoplankton was studied by water sampling in June but with net hauls in the other two months, only the total cell concentrations of May and October were compared. Total phytoplankton cell concentration was more variable in October with the minimal and maximal value $\left(0.5-9.5 \times 10^{5}\right.$ cells $\left.\mathrm{m}^{-3}\right)$ at the two stations located in Bohai Strait, but less variable in May $\left(0.8-1.8 \times 10^{5}\right.$ cells $\left.\mathrm{m}^{-3}\right)$.

\section{Pigment ingestion rate}

PIR at each station ranged from 1.57 to $11.86 \mu \mathrm{g}$ $\mathrm{C}$ female ${ }^{-1} \mathrm{~d}^{-1}$ in June, 1.18 to $5.69 \mu \mathrm{g} \mathrm{C}$ female $^{-1} \mathrm{~d}^{-1}$ in October and 3.06 to $12.98 \mu \mathrm{g} \mathrm{C}_{\text {female }}^{-1} \mathrm{~d}^{-1}$ in May (Table 1). The mean PIR in October was the lowest of the three analyzed periods. Despite similar chl- $a$ concentration in all periods, $C$. sinicus consumed less phytoplankton in October, approximately half of that consumed in June and one third of that consumed in May. At the two stations where dinoflagellates prevailed (Station E3 in October and B1 in May), PIR was 1.53 and $3.06 \mu \mathrm{g} \mathrm{C}$ female ${ }^{-1} \mathrm{~d}^{-1}$ respectively, far less than the average of each month. Except for these two stations, a weak logarithmical regression was found between chl- $a$ concentration and PIR or the herbivore index (Fig. 3).

\section{Egg production rate}

EPR was rather high in all three studies, which implies that reproduction was comparatively active in all of them. It was highest in May, averaging 3.54 $\mu \mathrm{g} \mathrm{C}$ female $^{-1} \mathrm{~d}^{-1}$ (Table 1). EPR in October was much more similar to that of June (2.23 and $2.11 \mu \mathrm{g}$ $\mathrm{C}$ female ${ }^{-1} \mathrm{~d}^{-1}$ respectively). It was relatively high at stations inside the Bohai Sea where chl- $a$ concentration was also high. EPR was 1.58 and $2.32 \mu \mathrm{g} \mathrm{C}$ female ${ }^{-1} \mathrm{~d}^{-1}$ at the two stations where dinoflagellates prevailed (st. E3 in October and B1 in May respec- 


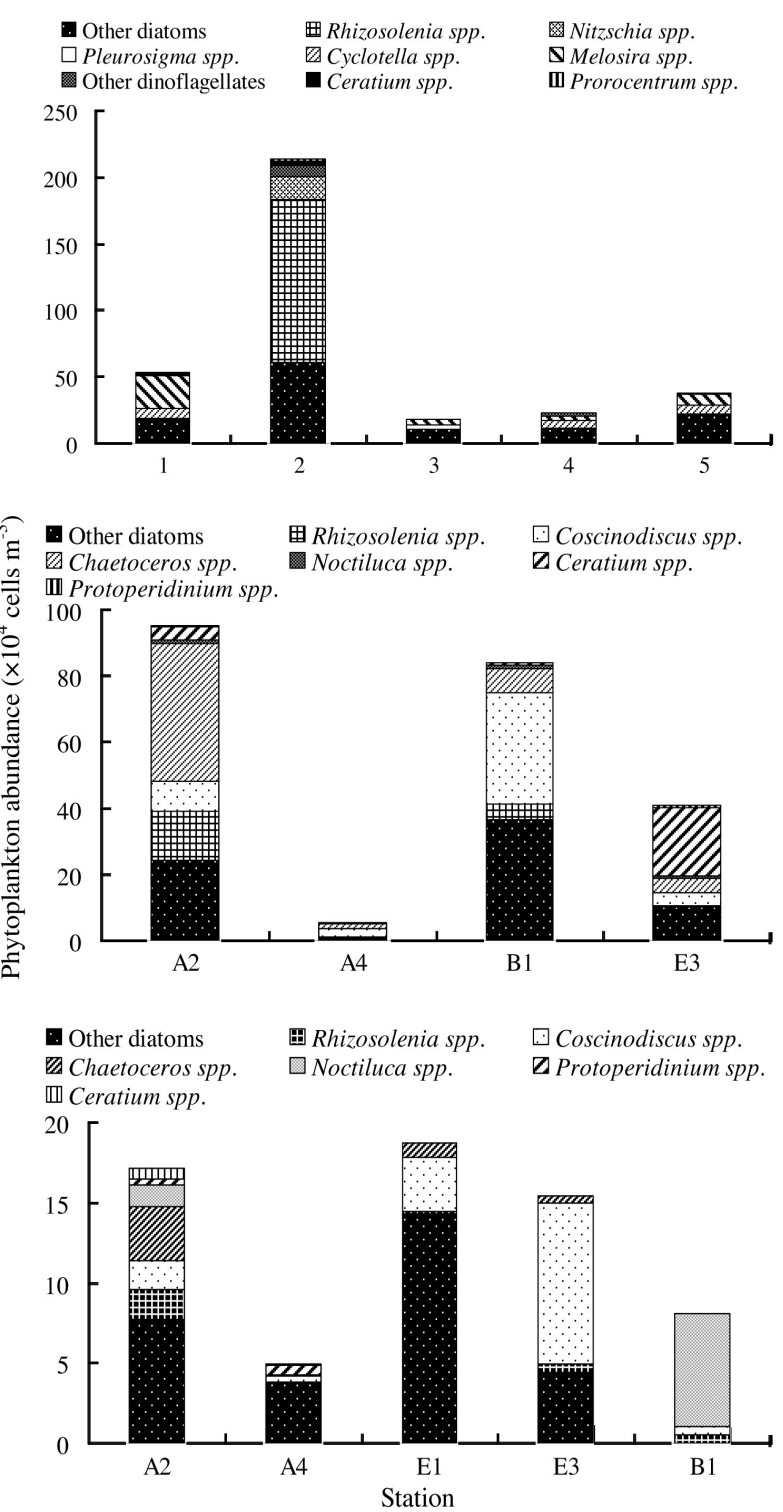

FIG 2. - Percentage composition of different phytoplankton groups during three cruises (From top: June, investigated with water samples by Niskin sampler; October, with net hauls; May, with net hauls)

tively), and also less than the average of each period. A weak linear correlation was found between EPR and chl- $a$ concentration (Fig. 3).

\section{Egg production efficiency and the Herbivore index}

When a regression equation was made between the PIR and EPR from all three cruises, its slope was 0.23 , which is lower than the constant 0.33 . However, the intercept was as high as $1.32 \mu \mathrm{g} \mathrm{C}$ female ${ }^{-1} \mathrm{~d}^{-1}$, which indicates that $C$. sinicus maintained an EPR of 6.6 eggs female ${ }^{-1} \mathrm{~d}^{-1}$ even when PIR was 0 . If the intercept is forced to 0 , the slope
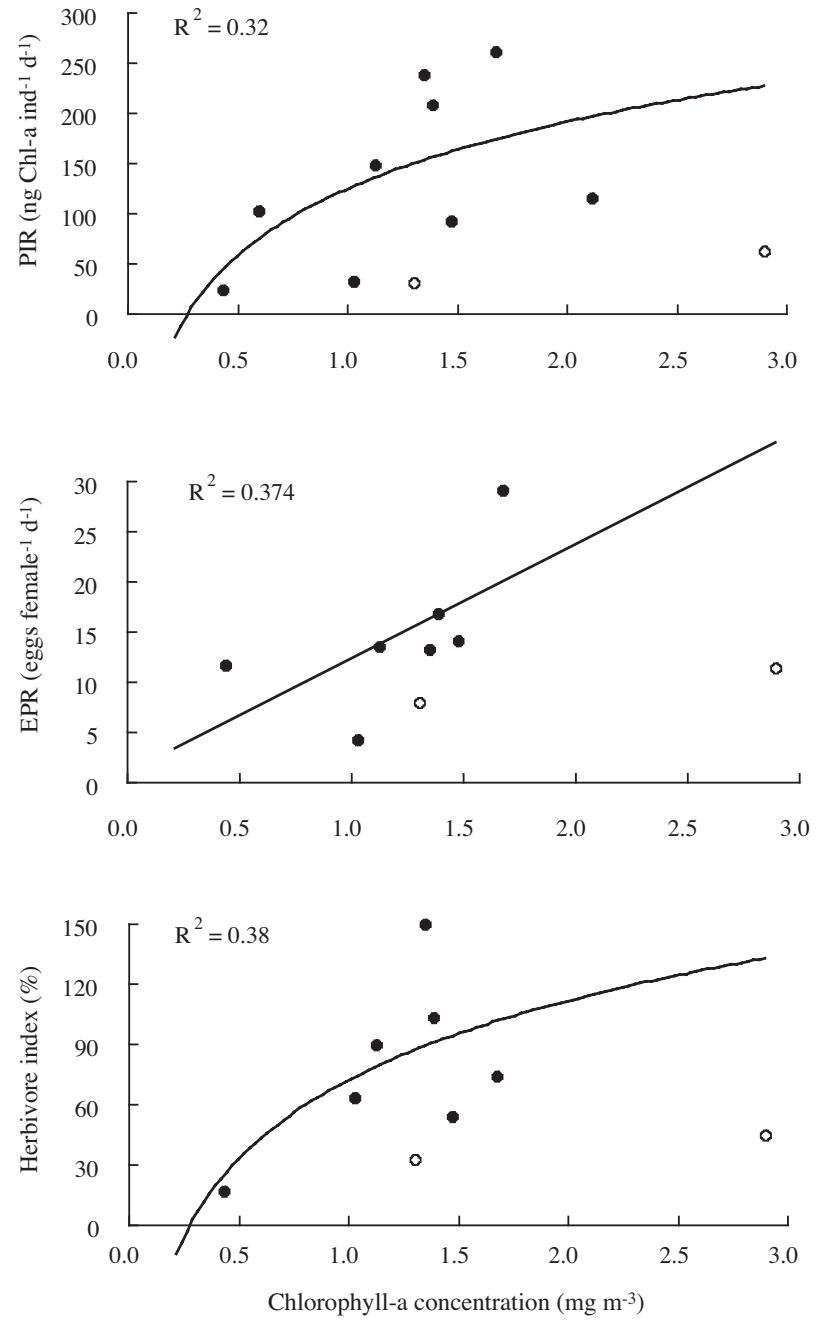

FIG 3. - Relationship between chlorophyll- $a$ concentration and (from top) pigment ingestion rate, egg production rate, herbivore index of C. sinicus at each station. (Regression line based on only fill dots representing stations diatoms prevailed, two circles represents the two stations dinoflagellates dominated).

of the regression equation is 0.37 , suggesting a herbivore index of $89 \%$ (Fig. 4). The results for $\mathrm{K}_{1}{ }^{\prime}$ exceeded 0.33 at most of the stations, which suggests that non-phytoplankton food items were exploited by $C$. sinicus in all of the study periods (Table 1).

According to the monthly average of PIR and EPR, the herbivore index was $100.0 \%$ in June, $47.8 \%$ in October and $82.5 \%$ in May respectively (Table 1), which suggests that omnivorous feeding contributed much more to egg production in October than the other two months. However, the herbivore index was higher than $100 \%$ at two stations: station 5 in June and E1 in May. At the two stations where dinoflagellates prevailed $\mathrm{H}$ was as low as 32.0 and $44.6 \%$, which indicates that they may avoid this type 


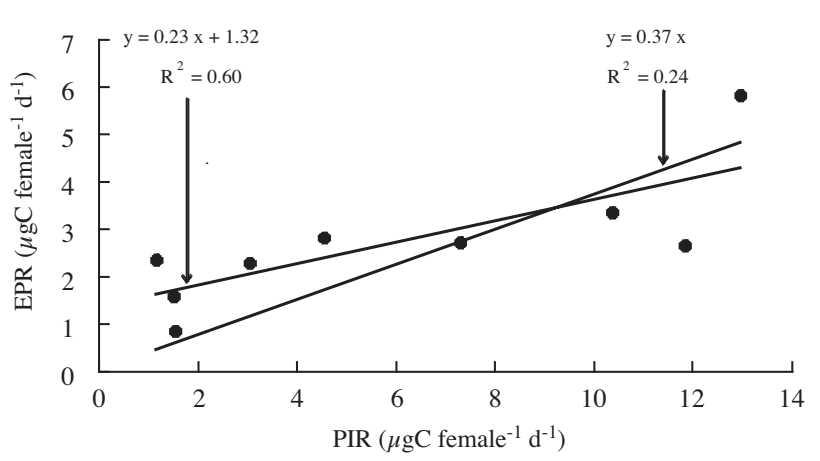

FIG 4. - Linear regressions between carbon specific pigment ingestion rate and egg production rate of $C$. sinicus, with and without intercept forced into 0 .

of food. Station A4 also had a low H (16.8\%), where Noctiluca spp. was also relatively abundant.

\section{DISCUSSION}

Our results were consistent with those found from gut content examination in the same area (Yang, 1997). The gut content examination showed that ciliates, which are the most abundant non-phytoplankton item, were only distinguished in the gut content in summer and autumn with a weight specific proportion of $4.0 \%$ and $2.7 \%$. On average, diatoms account for more than $99 \%$ of the weight specific gut content mass of $C$. sinicus in winter (February) and spring (May to June) but 94\% in autumn (November) and $72 \%$ in summer (August). The proportion of dinoflagellates in its diet was about $0.6 \%$ in winter and spring, $2.5 \%$ in autumn, but as high as $23 \%$ in summer. A similar conclusion that micro-zooplankton are unimportant to females in spring (from April to June) was reached in the Inland Sea of Japan (Uye and Murase, 1997). It is well known that gut content examination can be misleading due to food items having different gut passage times. Although they differed in absolute value, both gut content examination and our method revealed that omnivorous feeding played a more important role for $C$. sinicus from summer to autumn than in spring.

In our opinion, increased omnivorous feeding of C. sinicus in October was most probably due to phytoplankton assemblages and sufficient non-phytoplankton food resources. Species succession has been suggested for annual phytoplankton variation in the Bohai Sea: small-sized diatoms prevailed in spring but large-sized diatoms and dinoflagellates co-dominated during the autumn bloom (Sun et al., 2001). Phytoplankton larger than $76 \mu \mathrm{m}$ were quite scarce in spring but accounted for a significant proportion in autumn (Sun et al., 2002). Cells of this size seemed inaccessibly to $C$. sinicus. In our study, Coscinodiscus spp., Chaetoceros spp. and Ceratium spp., with comparatively large sizes, were found in large amounts in October, while in May other less abundant diatoms accounted for a large proportion at station A2, A4 and E1. The herbivore index was highest at station E1 in May, and egg production rate was higher at stations A2 and A4 than station B1, where chlorophyll- $a$ concentration was the highest.

The dominance of dinoflagellates in our study can also induce food shortage for $C$. sinicus, though chlorophyll- $a$ concentration was high. Heterotrophic Noctiluca spp. may compete for food resources with copepods. It was observed in different areas that a bloom of this species often accompanied a decrease in eggs and nauplii of copepods or the total biomass of zooplankton. Ceratium spp. has been suggested to be an unsuitable food for copepods because of its large size and intractability. When dinoflagellates dominated, Calanus finmarchicus fed non-selectively on dinoflagellates except Ceratium spp. (Cataletto et al., 1995). The feeding rate of $C$. finmarchicus increased rapidly with the cell diameter of the algae in the size range 7 to $17 \mu \mathrm{m}$ (ESD), and ciliates larger than $30 \mu \mathrm{m}$ were found to be rejected intensively (Teegarden et al., 2001). Although studies on the upper size limit of its food particles were unavailable, phytoplankton as large as $76 \mu \mathrm{m}$ might be unsuitable for $C$. sinicus. At the Ceratium species dominated station E3 in October and the Noctiluca species dominated station B1 in May, the pigment ingestion rate and the herbivore index of $C$. sinicus were lower than stations with similar chlorophyll- $a$ concentration.

In addition, it seems that the microbial loop plays a more important role in autumn than in spring (Nejstgaard et al., 2001). Microorganisms are usually inaccessible to copepods, but they can be utilized after they aggregate or colonize detritus particles or through cascade feeding (Boak and Goulder, 1983; Lawrence et al., 1993). The ratio of bacteria production to primary production in the Bohai Sea was 0.38 in May, and 0.21 in October, which indicates that bacteria contributed a larger proportion to the total production in spring (Xiao, 1999), but Synechococcus measured by epifluorescence microscopy was much more abundant in October 
than in May, with a biomass of 0.37 to $16.6 \mathrm{mg} \mathrm{C}$ $\mathrm{m}^{-3}$ and 0.03 to $0.44 \mathrm{mg} \mathrm{C} \mathrm{m}^{-3}$ respectively. The highest biomass in October appeared at station A4, where the phytoplankton contribution to egg production of $C$. sinicus was also the lowest. Though data on protozoan was too scarce to give a regression equation, seasonal variation of micro-zooplankton biomass coincided well with the feeding selectivity of $C$. sinicus. In May, aloricate ciliates were scarce and there were mainly tintinnidae. Aloricate ciliates were rather abundant in October, when $C$. sinicus changed to evident omnivorous feeding. Micro-zooplankton was much more abundant at stations A4 and E3 in October. Its abundance was highest at 18:00 and changed significantly in $24 \mathrm{~h}$ (Zhang, 1999), which is consistent with the feeding rhythm of $C$. sinicus. Since most protozoa were simple in body structure and were cleared rapidly by copepods, their contribution may be underestimated by traditional gut content examination. Detritus and their own eggs, as well as eggs and nauplii of other zooplankton species, can all be a part of the diet of C. sinicus, as cannibalism has been suggested to be the most important source of egg mortality (Zhang et al., 2001).

Carbon specific PIR and EPR were used in this article instead of nitrogen specific PIR and EPR (Dam et al., 1994), since both of them were converted from pigment content and the number of eggs. In fact, although not used for measuring feeding habit, linear regression between the pigment ingestion rate and EPR has been observed in many previous studies, including small copepod Acartia tonsa and $C$. finmarchicus of similar body size with C. sinicus (Kiørboe et al., 1985; Båmstedt et al., 1999; Kleppel and Hazzard, 2000). In this study, the herbivore index may deviate in absolute value, but seasonal alternation of feeding habit shows that the hypothesis that $C$. sinicus consumes more non-phytoplankton food items during the autumn bloom tends to be reliable.

\section{ACKNOWLEDGEMENTS}

We would like to thank Prof. H. Wei for providing CTD data from all three cruises. Support from the National Key Basic Research Program of China to R. Wang, from the Science and Technology Ministry of China (973-G1999043708 and 2006CB400606) to S. Sun, and from the National
Natural Science Foundation of China (40106016) to C. -L. Li are acknowledged.

\section{REFERENCES}

Atkinson, A. - 1996. Subantarctic copepods in an oceanic, low chlorophyll environment: ciliate predation, food selectivity and impact on prey populations. Mar. Ecol. Prog. Ser., 130: 85-96.

Båmstedt, U., P.T. Scolberg and J.C. Nejstgaard. - 1999. Utilization of small-size food algae by Calanus finmarchicus (copepoda: Calanoida) and the significance of feeding history. Sarsia, 84: 19-38.

Båmstedt, U., D.J. Gifford, X. Irigoien, A. Atkinson and M. Roman. - 2000. Feeding. In: R. Harris (ed.), ICES Zooplankton Methodology Manual, pp. 297-380. Academic Press, New York.

Ban, S., C. Burns, J. Castel, Y. Chaudron, E. Christou, R. Escribano, S.F. Umani, S. Gasparini, G.F. Ruiz, M. Hoffmeyer, A. Ianora, H.K. Kang, M. Laabir, A. Lacoste, A. Miralto, X. Ning, S. Poulet, V. Rodriguez, J. Runge, J. Shi, M. Starr, S.I. Uye and Y. Wang. - 1997. The paradox of diatom-copepod interactions. Mar. Ecol. Prog. Ser., 157: 287-293.

Ban, S.H., H.W. Lee, A. Shinada and T. Toda. - 2000. In situ egg production and hatching success of the marine copepod Pseudocalanus newmani in Funka Bay and adjacent waters off southwestern Hokkaido, Japan: associated to diatom bloom. $J$. Plankton Res., 22: 907-922.

Boak, A.C. and R. Goulder. - 1983. Bacterioplankton in the diet of the calanoid copepod Eurytemora spp. in the Humber Estuary. Mar. Biol., 73: 139-149.

Cataletto, B., E. Feoli, S.F. Umani and C.Y. Sun. - 1995. 11 years of time-series analysis on the net-zooplankton community in the Gulf-of-Trieste. ICES J. Mar. Sci., 52: 669-678.

Dam, H.G., W.T. Peterson and D.C. Bellantoni. - 1994. Seasonal feeding and fecundity of the Calanoid copepod Acartia tonsa in Long-Island Sound - is omnivory important to egg production? Hydrobiologia, 293: 191-199.

Harris, R.P. - 1996. Feeding ecology of Calanus. Ophelia, 44: 85-109.

Ianora, A., S.A. Poulet and A. Miralto. - 2003. The effects of diatoms on copepod reproduction: a review. Phycologia, 42: 351-363.

Kang, H.K. and S.A. Poulet. - 2000. Reproductive success in Calanus helgolandicus as a function of diet and egg cannibalism. Mar. Ecol. Prog. Ser., 201: 241-250.

Kiørboe, T., F. Møhlenberg and H. Nicolajsen. - 1985. Bioenergetics of the planktonic copepod Acartia tonsa: relation between feeding, egg production and respiration, and composition of specific dynamic action. Mar. Ecol. Prog. Ser., 143: 85-97.

Kleppel, G.S. - 1993. On the diets of calanoid copepods. Mar. Ecol. Prog. Ser., 99: 183-195.

Kleppel, G.S. and S.E. Hazzard. - 2000. Diet and egg production of the copepod Acartia tonsa in Florida Bay. II. Role of the nutritional environment. Mar. Biol., 137: 111-121.

Lacoste, A., S.A. Poulet, A. Cueff, G. Kattner, A. Ianora and M. Laabir. - 2001. New evidence of the copepod maternal food effects on reproduction. J. Exp. Mar. Biol. Ecol., 259: 85-107.

Lawrence, S.G., A. Ahmad and F. Azam. - 1993. Fate of particlebound bacteria ingested by Calanus pacificus. Mar. Ecol. Prog. Ser., 97: 299-307.

Li, C., R. Wang and S. Sun. - 2003. Grazing impact of copepods on phytoplankton in the Bohai Sea. Est. Coast. Shelf Sci., 58: 487-498.

Mackas, D. and R. Bohrer. - 1976. Fluorescence analysis of zooplankton gut contents and an inbestigation of diel feeding patterns. J. Exp. Mar. Biol. Ecol., 25: 77-85.

Miralto, A., L. Guglielmo, G. Zagami, I. Buttino, A. Granata and A. Ianora. - 2003. Inhibition of population growth in the copepods Acartia clausi and Calanus helgolandicus during diatom blooms. Mar. Ecol. Prog. Ser., 254: 253-268.

Nejstgaard, J.C., B.H. Hygum, L.J. Naustvoll and U. Båmstedt. 2001. Zooplankton growth, diet and reproductive success compared to simultaneous diatom- and flagellate- microzooplankton dominated plankton blooms. Mar. Ecol. Prog. Ser., 221: 77-91. 
Peterson, W.T. and H.G. Dam. - 1996. Pigment ingestion and egg production rate of the copepod Temora longicornis: implication for gut-pigment loss and omnivorous feeding. J. Plankton Res., 18: 855-861.

Plourde, S. and J.A. Runge. - 1993. Reproduction of the planktonic copepod Calanus finmarchicus in the Lower St. Lawrence Estuary: relation to the cycle of phytoplankton production and evidence for a Calanus pump. Mar. Ecol. Prog. Ser., 102: 217-227.

Runge, J.A. - 1985. Egg production rates of Calanus finmarchicus in the sea off Nova Scotia. Ergebn. Limnol., 25: 33-40.

Runge, J.A. and J.C. Roff. - 2000. The measurement of growth and reproductive rates. In: R. Harris (ed.), ICES Zooplankton Methodology Manual, pp. 297-380. Academic Press, New York.

Sun, J., D.Y. Liu and S.B. Qian. - 2001. Preliminary study on the seasonal succession and development pathway of phytoplankton community in the Bohai Sea. Acta Oceanol. Sin., 20(2): 251-260.

Sun, J., D.Y. Liu, S.M. Yang, F. Guo and S.B. Qian. - 2002. The preliminary study on phytoplankton community structure in the central Bohai Sea and the Bohai Strait and its adjacent areas. Oceanol. Liminol. Sin., 33(5): 461-471. (In Chinese with English abstract)

Teegarden, G.J., R.G. Campbell and E.G. Durbin. - 2001. Zooplankton feeding behavior and particle selection in natural plankton assemblages containing toxic Alexandrium spp. Mar. Ecol. Prog. Ser., 218: 213-226.

Turner, J.T., A. Ianora, , Miralto, A., M. Laabir and F. Esposito. 2001. Decoupling of copepod grazing rates, fecundity and egghatching success on mixed and alternating diatom and dinoflagellate diets. Mar. Ecol. Prog. Ser., 220: 187-199.

Uye, S.I. - 1988. Temperature-dependent development and growth of Calanus sinicus (Copepoda: Calanoida) in the laboratory. Hydrobiologia, 167/168: 285-293.
Uye, S.I. and A. Murase. - 1997. Relationship of egg production rates of the planktonic copepod Calanus sinicus to phytoplankton availability in the Inland Sea of Japan. Plankton Biol. Ecol., 44(1/2): 3-11.

Wang, R. and R.J. Conover. - 1986. Dynamics of gut pigment in the copepod Temora longicornis (Muller) and the determination of in situ grazing rates. Limnol. Oceanogr., 31: 867-877.

Willason, S.W. and J.L. Cox. - 1987. Diel feeding, laminarinase activity and phytoplankton consumption by Euphausiids. Biol. Oceanogr., 4: 1-24.

Xiao, T. - 1999. The study on distributions of bacterioplankton biomass and production in the coastal waters of China. Ph.D Dissertation. Institute of Oceanology, Chinese Academy of Sciences. (In Chinese with English abstract).

Yang, J. - 1997. Primary study on the feeding of the Bohai Sea Calanus sinicus. Oceanol. Liminol. Sin., 28: 376-382. (In Chinese with English abstract).

Yu, J. and R. Li. - 1993. The study on the phytoplankton ecology in the Bohai Sea and the Yellow Seas. J. Oceanogr. Huanghai Bohai Seas, 11: 52-59. (In Chinese with English abstract).

Zhang, W.C. - 1999. Microzooplankton and their grazing pressures on phytoplankton. Ph.D thesis. Institute of Oceanology, Chinese Academy of Sciences. (In Chinese with English abstract).

Zhang, G.T., S. Sun, B. Yang, Y.S. Zhang and P. Ji. - 2001. Egg mortality of Calanus sinicus and Paracalanus parvus. Oceanol. Liminol. Sin., Special Issue: 78-84. (in Chinese with English abstract).

Scient. ed.: A. Ianora

Received November 4, 2005. Accepted February 6, 2006.

Published online July 6, 2006. 